\title{
县 \\ KOMUNIKASI RITUAL PADA TRADISI PARANG PISANG DI NAGARI SURANTIH, KABUPATEN PESISIR SELATAN, SUMATERA BARAT
}

\author{
Zike Martha ${ }^{1}$ \\ ${ }^{1}$ Program Ilmu Komunikasi Universitas Dharma Andalas, Padang \\ Email : zikemartha17@gmail.com
}

\begin{abstract}
Abstrak
Tradisi parang pisang merupakan sebuah kegiatan yang masuk ke dalam kategori komunikasi ritual. Dalam tradisi ini terdapat makna untuk memperingati lahirnya bayi kembar sumbang sehingga dipercaya agar tidak timbulnya perasaan suka antara satu sama lain. Penelitian ini bertujuan untuk mengetahui makna dan simbol yang terdapat dalam tradisi parang pisang serta pemahaman generasi muda dalam memaknai tradisi ini. Dalam penelitian ini, peneliti mendapatkan infromasi melalui 7 (tujuh) orang narasumber yang dipercayai kebenaran informasi yang diberikan. Metode yang digunakan dalam penelitian ini adalah metode kualitatif dengan menggunakan teori interaksional simbolik. Hasil dari penelitian menunjukkan bahwa terdapat simbol verbal dan non verbal dalam tradisi parang pisang ini. Simbol verbal tersebut berupa petatah petitih minang yang digunakan dalam proses berkomunikasi selama acara berlangsung. Adapun simbol non verbalnya yaitu terdapat benda-benda dan peralatan yang digunakan dimana setiap benda yang digunakan mengandung makna dan arti.
\end{abstract}

Kata Kunci : Tradisi, Komunikasi Ritual, Parang Pisang, Nagari Surantih.

\begin{abstract}
The parang pisang tradition is an activity that falls into the category of ritual communication. In this tradition there is a meaning to commemorate the birth of discordant twins so it is believed that there will be no feelings of love for one another. The reseacrh aims to determine the meaning and symbols contained in the parang pisang tradition and the understanding of the younger generation in interpreting this tradition. In this research, information was obtained through 7 (seven) speakers who fit the research criteria. The method used in this research is a qualitative method using syimbolic interactional theory. The results of the study indicate that there are verbal dan non verbal symbols in the tradition of this parang pisang. Verbal symbols in the form of minang rhymes used in the process of communicating during the event. As for non verbal symbols, there are obejcts and equipment used where every object used contains meaning.
\end{abstract}

Keywords : Tradition, Ritual Communication, Parang Pisang, Nagari Surantih 


\section{LATAR BELAKANG}

Sebagaimana dikatakan Sair (2019), Indonesia merupakan negara yang sangat besar. Jumlah penduduknya hingga tahun 2019 telah mencapai 269 juta jiwa (Worldometer, 2019). Jumlah tersebut menyebar di berbagai penjuru tanah air. Sebagai negara besar, Indonesia juga menjadi negara dengan tingkat keragaman yang paling banyak di dunia. Mulai dari suku, agama, bahasa, budaya, hingga adat istiadat yang menyatu dalam bingkai Negara Kesatuan Republik Indonesia (NKRI). Penyatuan ini kemudian dikenal dengan semboyan Bhinneka Tunggal Ika, yakni berbeda-beda dalam satu kesatuan. Keragaman di atas terus dijaga hingga sekarang dengan memprakekkan dalam kehidupan sehari-hari.

Sebagai negara kebudayaan yang tercermin dalam berbagai aspek kehidupan masyarakat sehari-hari. Kebudayaan tersebut kini menjadi identitas dengan berbagai ciri khas masing-masing. Salah satu kebudayaan tersebut yang mentradisi hingga sekarang adalah tradisi parang pisang di Nagari Surantiah, tepatnya di Kabupaten Pesisir Selatan, Propinsi Sumatera Barat. Tradisi parang pisang ini merupakan kebudayaan lokal yang terjaga hingga sekarang. Setiap masyarakat yang melakukan tradisi ini meyakini sebagai peninggalan nenek moyang terdahulu yang harus lestarikan. Suprayogo (dalam Ghozali, 2014) menjelaskan bahwa tradisi seperti parang pisang ini pada dasarnya adalah rangkaian kata, tindakan pemeluk agama dengan menggunakan benda-benda, peralatan dan perlengkapan tertentu, ditempat tertentu dan memakai pakaian tertentu pula.

Sebagimana diketahui, bahwa tradisi parang pisang ini merupakan sebuah tradisi yang telah ada sejak zaman dahulu yang diturunkan secara turun temurun oleh para leluhur mereka. Kearifan lokal ini sudah sangat populer dan dikenal oleh masyarakat sekitar karena keunikan dalam proses pelaksanaannya. Tradisi ini dilakukan untuk memperingati atau merayakan jika terlahir bayi kembar sumbang, dimana bayi kembar sumbang ini adalah bayi kembar yang terdiri dari laki-laki dan perempuan. Tujuan dari tradisi ini adalah untuk memisahkan batin si bayi agar tidak timbulnya perasaan saling suka satu sama lain ketika mereka sudah dewasa nanti. Sebab tradisi ini meyakini bahwa, bayi yang telah bersama sejak dalam kandungan batin mereka akan menyatu.

Tradisi parang pisang ini dianggap unik karena nama dan bentuk perayaannya yang dilakukan dengan melemparkan pisang oleh kedua pihak keluarga. Parang merupakan bahasa minang yang berarti perang. Sementara pisang adalah buah. Parang pisang memiliki arti yaitu perang dengan menggunakan pisang sebagai alatnya. Parang pisang tersebut dilakukan oleh dua keluarga, yaitu keluarga si bayi kembar dan keluarga Induak Bako (keluarga terdekat, seperti kakak atau adik kandung yang perempuan dari bapak/ayah, sedangkan yang agak jauh bisa berasal dari kakak atau adik kandung dari ayah istri). Kegiatan parang pisang ini selalu mampu menarik perhatian masyarakat karena keseruan yang dihadirkan dalam aksi saling lempar pisang tersebut.

Sejauh ini para sarjana yang mendalami tradisi ini masih terbatas, bahkan dapat dikatakan belum banyak sarjana yang mendalami masalah parang pisang ini sebagai kajian ilmiah. Kajian-kajian yang sudah ada masih sebatas kajian biasa yang tidak menyorot parang pisang secara komprehensif. Padahal tradisi parang pisang merupakan tradisi mengesankan yang dapat dikembangkan sebagai kebudayaan masyarakat Padang, sehingga ke depan selain dapat menjadi identitas kebudayaan masyarakat setempat, juga dapat menjadi daya tarik masyarakat luar untuk mengetahui secara langsung praktik tradisi parang pisang tersebut. Apalagi ditengah perkembangan teknologi dan ilmu pengetahuan seperti saat sekarang ini, 
masyarakat dihadapkan pada benturan dengan kebudayaan luar untuk terus mempertahankan tradisi tersebut. Belum lagi pemahaman generasi muda yang danggap mulai berbeda. Generasi muda sudah dianggap mulai tidak memahami makna tradisi leluhur itu. Bahkan mereka mulai tidak memahami alur dari tradisi tersebut, tidak mengetahui keberadaannya yang diakibatkan oleh perkembangan zaman dan gaya hidup serta pergaulan generasi muda yang kian glamour. Oleh karena itu, artikel ini di sisi lain ingin menjelaskan tradisi parang pisang ini sebagai komunikasi ritual. Sebab bagaimanapun, tradisi parang ini memiliki pesan simbolik yang perlu dipahami dalam kehidupan sehari-hari.

\section{METODE}

Artikel ini berbasis penelitian, peneliti menggunakan metode kualitatif dengan pendekatan deskriptif untuk memahaminya. Menurut Afrizal (2014) penelitian kualitatif adalah suatu penelitian yang melihat fenomena, situasi, dan kejadian yang terjadi di suatu wilayah masyarakat atau kelompok. Dalam penelitian desktiptif kualitatif, peneliti mendapatkan informasi atau data secara lebih mendalam mengenai suatu permasalahan serta informasi atau data yang diperoleh seara akurat yang sesuai dengan inti permasalahan yang sedang didalami. Lokasi penelitian ini dilakukan di Nagari Surantiah Kecamatan Sutera Kabupaten Pesisir Selatan. Peneliti mengamati dan melakukan wawancara secara langsung guna mendapatkan informasi mengenai tradisi unik Parang Pisang. Informan dalam penelitian ini ditentukan secara purposive. Menurut Sugiyono (2013) teknik purposive adalah pemilihan informan berdasarkan pada karakteristik tertentu yang dianggap mempunyai sangkut pautnya dengan karakteristik populasi yang sudah diketahui sebelumnya.
Pada penelitian ini, peneliti mendapatkan 2 informan kunci dan informan pendukung. Informan kunci adalah karakteristik yang memberikan informasi secara rinci sesuai dengan apa yang diteliti dan dibutuhkan oleh peneliti. Karakteristik informan kunci berdasarkan kriteria peneliti, yaitu, merupakan penduduk asli Surantiah (merujuk pada Kartu Tanda Penduduk), memahami adat istiadat parang pisang, mempunyai wawasan yang dalam terhadap budaya masyarakat Surantiah, merupakan panutan yang dipercaya oleh masyarakat setempat. Sementara karakteristik informan pendukung adalah informan yang memberikan opini terhadap fenomena yang diteliti oleh peneliti. Karakteristik informan pendukung berdasarkan kriteria peneliti, yaitu, merupakan masyarakat asli Surantiah (merujuk pada Kartu Tanda Penduduk), merumur 17 tahun ke atas, pernah mengikuti atau melihat proses tradisi parang pisang kembar sumbang. Bayi kembar sumbang yaitu bayi kembar yang lahir laki-laki dan perempuan.

\section{NAGARI SURANTIH}

Nagari Surantih merupakan sebuah desa yang terletak di Kecamatan Sutera, Kabupaten Pesisir Selatan, Provinsi Sumatra Barat. Sebagai nagari, Surantih menjadi wilayah dengan jumlah penduduk 8024 jiwa (tahun 2018) yang terdiri dari 4035 laki-laki dan 3989 perempuan, serta 1842 rumah tangga (RT). Luas wilayah Desa Surantih adalah 26,78 kilometer persegi atau 6,01 persen dari luas wilayah Kecamatan Sutera. Sebagai desa, Surantih juga memiliki 2 kampung dan memiliki 14 aparat nagari. Jarak nagari Surantih ke Kantor Wali Nagari dan atau ke Ibu kota Kecamatan adalah sejauh 1,8 kilometer, sementara ke Painan sejauh 37 kilometer dan ke Kota Padang sejauh 114 kilometer (Palanta, 22 Maret 2020). 
Surantih disebut nagari karena berada dalam sistem pemerintahan Sumatera Barat yang mengistilahkan pemerintahan desa dengan istilah nagari. Nagari sendiri merupakan pembagian wilayah administratif sesudah kecamatan di provinsi Sumatra Barat. Secara etimologi, nagari berasal dari kata nagarom yang memiliki arti tanah air, tanah asal, atau tanah kelahiran. Namun dalam konteks kesatuan, nagari diartikan sebagai kesatuan masyarakat hukum yang memiliki batas-batas wilayah yang berwenang untuk mengatur dan mengurus kepentingan masyarakat setempat, berdasarkan asal usul dan adat istiadat yang diakui dan dihormati dalam sistem pemerintahan Negara Kesatuan Republik Indonesia. Sebagai kesatuan wilayah, nagari terdiri dari Jorong/Korong yang memiliki tujuan dan prinsip yang sama. Nagari juga dipimpin oleh seorang Wali Nagari. Wali Nagari dipilih melalui musyawarah dan mufakat dari berbagai kumpulan Jorong dan masyarakat melalui pemilihan wali nagari atau dikenal dengan Pilwana (https://id.wikipedia.org/ wiki/Nagari).

\section{PROSES TRADISI PARANG PISANG}

Tradisi parang pisang merupakan suatu tradisi daerah yang diwariskan secara turun-temurun di daerah Surantih. Tradisi ini termasuk ke dalam kearifan lokal masyarakat Minangkabau khususnya di Kabupaten Pesisir Selatan. Adanya tradisi ini untuk memperingati lahirnya bayi kembar sepasang. Menurut informan yang bernama Rosmai, tradisi ini mulai dilakukan khalayak sejak tahun 1940-an (Tetapi bisa jadi, tradisi ini sudah dilakukan jauh sebelum tahun itu). Tradisi ini bermula ketika masyarakat meyakini sebuah cerita yang dilakukan secara turun-temurun dan terus dilakukan dari generasi ke generasi tentang sebuah keluarga yang memiliki bayi kembar sepasang. Konon, di tanah kelahiran itu ada sebuah keluarga yang melahirkan anak kembar sepasang. Kemudian, dalam proses perjalanan hidupnya, mereka saling jatuh cinta dan akhirnya menikah. Pernikahan sedarah inilah, yang menjadi aib dan harus dicegah dikemudian hari (Kayo, 6/8/2015).

Banyak cerita yang berkembang kemudian bahwa, pengalaman keluarga yang memiliki bayi kembar sepasang tersebut dianggap suatu keanehan dan mereka mempercayai kejadian itu adalah sebagai pertanda yang tidak baik. Kelahiran bayi kembar laki-laki dan perempuan itu kemudian menjadi sangat tabu dikalangan masyarakat hingga sekarang, yang bisa jadi, keyakinan itu disebabkan oleh cara pandang yang keliru dan minimnya pengetahuan masyarakat tentang bayi kembar sepasang. Atas keyakinan itu, masyarakat melakukan tradisi ini sebagai proses ritual untuk menghalau pertanda buruk yang akan terjadi melalui kegiatan yang dikenal dengan parang pisang. Parang pisang menjadi semacam perayaan untuk memperingati dan mendoakan agar bayi kembar sepasang (laki- laki dan perempuan) tersebut tidak jatuh cinta dikemudian hari, yang bagi masyarakat di nagari itu adalah hal yang buruk. Selain itu, tradisi parang pisang ini sekaligus untuk memberitahukan kepada khalayak ramai bahwa telah lahir bayi kembar sepasang dimana nantinya ketika mereka telah dewasa tidak menimbulkan fitnah di masyarakat jika mereka terlihat jalan berdua. Bagi mereka, menggelar parang pisang, adalah harapan agar dikemudian hari si kembar itu tak mengalami nasib serupa seperti yang pernah terjadi dulunya, yakni menikah dengan saudara kembarnya. Atau dalam bahasa lain, tradisi parang pisang ini agar dapat memutus kasih batin pada kedua bayi tersebut. Yang secara medis, perkawinan sedarah ini, atau yang dikenal incest, merupakan sistem pernikahan antara dua (2) orang yang berasal dari satu (1) garis keturunan keluarga. Perkawinan sedarah ini 
selain tabu, juga bisa menimbulkan permasalahan kesehatan, terutama pada keturunannya nanti (HonestDocs, 4 Juli 2019).

Prosesi tradisi parang pisang dimulai dengan arak-arakan keluarga Induak Bako menuju rumah keluarga si bayi (rumah keluarga perempuan). Mereka membawa bakul (tempat nasi) yang berisi penuh dengan pisang rebus. Pisang tersebut, nantinya bukan untuk dimakan bersama, melainkan sebagai "senjata" untuk dilemparkan ke keluarga perempuan. Dalam arak-arakan keluarga induak bako itu, terdapat pula si muntu, kudo kepang, anak daro. Selama arak-arakan berlangsung diiringi dengan musik tradisional seperti talempong dan sarunai. Kemeriahan arak-arakan ini disaksikan oleh seluruh warga kampung di sekitar.

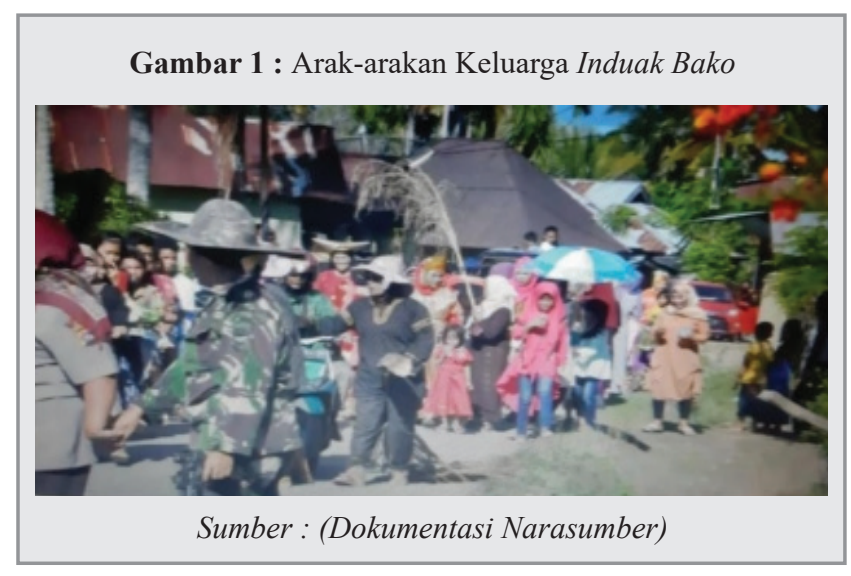

Setelah tiba di rumah keluarga perempuan, Induak bako memprotes dengan cara berteriak ke keluarga si bayi karena membiarkan si bayi beda jenis kelamin hidup dalam satu rumah. Penggabungan dua bayi dalam satu rumah ini dianggap oleh pihak induak bako sebagai bentuk awal mulanya malapetaka. Seorang informan bernama Sri Yuliyesti menjelaskan proses itu sebagai berikut:

"Anak mincacak anak mincacau, anak singiang singiang rimbo, anak cancang pangarai. Indak bahulu ba aja sampai hati manyimpan bujang jo gadih salapiak sapatiduan baduo-duo dalam kulambo romen.
Kami induak bako mangandak mambaok pulang salah ciek supayo indak tajadi cilako" (Anak yang datang ke dunia, anak dalam rimbo singgang, anak yang baru datang, dari hulu, untuk menyimpan anak bujang/anak laki baru balik sama anak perempuan baru menuju gadis, duduk di tikar berduan, dalam tempat kamar tidur, kami dari ibu keluarga besar mau membawa pulang, salah satu anak bujang atau anak gadis agar tidak terjadi malapetaka kedepannya).

Dalam proses ini, induak bako juga bermaksud untuk mengambil salah satu dari si bayi. Tujuannya adalah untuk memisahkan mereka. Namun, tujuan mengambil salah satu bayi tersebut mengalami penolakan dari keluarga si bayi. Atas penolakan itu, induak bako memilih untuk melakukan perang karena tidak terima niat baik mereka di tolak. Perang-pun terjadi, yang dimulai dengan adu mulut dari kedua belah pihak, yang terdengar seperti berbalas pantun. Adu mulut itu adalah kode dan awal perang akan segera dimulai. Perang-pun tiba, peluru yang mereka pakai adalah buah pisang yang dibawa oleh induak bako yang awalnya sebagai buah tangan. Kedua belah pihak kemudian saling terlibat perang pisang dan warga sekitar juga ikut nimbrung dalam perang tersebut, sehingga suasana seperti sedang terjadi kekacauan.

Dari keluarga induak bako mengucapkan begini:

"Di asak sak bajak diasak sapamatang satapak indak ka di anjak ntah kok di nyawa kok tak sadang”. (Digarap bajak kerbau tempat tanah satu petak/satu hektar mau di buang kenapa nyawa nyawa harus melayang)

Sementara dari keluarga bayi akan mengatakan begini:

"Dicancang cancang batang kaladi di ulua 
aia di bandakan, usah diulang kato tadi maramang bulu mandangakan". (Di potongpotong ubi keladi/ubi jalar, tidak usah di ulang kata-kata yang tidak baik/yang tersingung dalam hati/kata kasar/kata kurang baik).

Dibalas lagi oleh keluarga induak bako dengan mengatakan begini:

"Kalau ndak namuah di amankan gunuang rajo batu mandamai jalan urang ka bangkahulu kalau nak cocok pakailah damai kalau nak parang giiang lah paluru”. (Kalau tidak mau di damaikan antara anak gadis dan buang maka secepatnya harus ke kantor penghulu kalau tidak cocok maka berdamailah agar tidak terjadi salah paham kedepan).

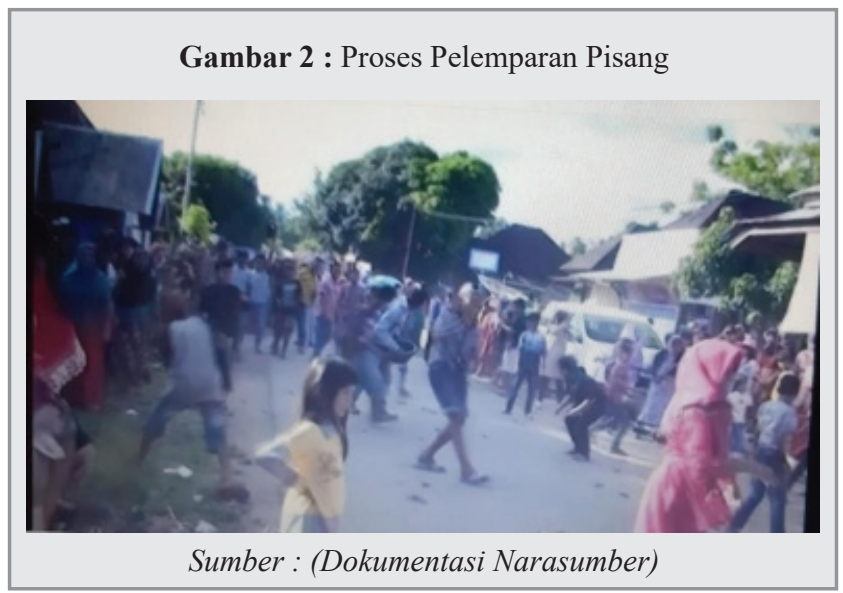

Akhir dari proses perang pisang ini ditandai dengan ajakan damai oleh keluarga si bayi dengan diberikannya siriah langguai (daun sirih) oleh keluarga si bayi ke induak bako. Pemberian siriah langguai merupakan suatu simbol permintaan maaf oleh keluarga si bayi ke induak bako. Permohonan maaf itu menjadi akhir dari parang pisang tersebut dan kedua belah pihak kumpul kembali. Namun ada realitas yang berbeda, jika dulu, parang pisang dilakukan secara serius, melemparnya dengan sangat kencang (keras), maka sekarang tidak demikian. Parang pisang dilakukan sambil tersenyum, bahkan ada yang tertawa, dan melemparnya juga tidak terlalu keras, layaknya perang yang sebenarnya.

\section{SIMBOL-SIMBOL KOMUNIKASI RITUAL PARANG PISANG}

Sebagaimana telah disinggung di atas, tradisi parang pisang merupakan tradisi adat pada masyarakat Surantih di Sumatera Barat. Tepatnya di Nagari Surantih Kecamatan Sutera Kabupaten Pesisir Selatan. Dalam tradisi parang pisang tersebut ada banyak makna dan nilai-nilai kehidupan. Mulai setiap langkah atau bagian-bagian dari tradisi hingga bawaan, serta simbol perlambangan lainnya. Semuanya mengandung makna dan nilai yang dimengerti oleh setiap warga yang terlibat dalam proses tersebut. Dalam konteks ilmu sosial, setiap makna tersebut memiliki unsur komunikasi (pesan) yang secara simbolik direpresentasikan dalam sepanjang tradisi itu.

Pesan dalam tradisi parang pisang di atas tentu menjadi unsur yang penting. Sebab, itu menjadi pengetahuan dan narasi kehidupan sosial yang sejatinya dapat dipahami oleh banyak orang. Walau hanya dengan komunikasi (pesan) simbolik, tradisi parang pisang juga tidak akan bisa dimengerti, bahkan tidak akan menjadi sebuah tradisi, manakala didalamnya tidak ada pesan sosial sebagai inti dari proses komunikasi tersebut. Pesan menjadi penting yang terdiri dari rangkaian penggunaan simbol-simbol atau kode-kode, baik secara verbal atau secara non verbal. Sebagaimana dikatakan Cangara (2014), simbol-simbol yang banyak digunakan oleh masyarakat dalam kehidupan sosial itu terdiri dari dua bagian, pertama simbol umum yang digunakan menurut konvensi internasional (seperti simbol lalu lintas, alphabet latin, simbol matematika), dan simbol-simbol lokal yang hanya dapat dipahami oleh kelompok-kelompok masyarakat tertentu, seperti masyarakat Surantih. 
Simbol-simbol di atas juga dapat dibagi atas dua bagian, yaitu simbol verbal dan simbol non verbal. Simbol verbal adalah proses komunikasi yang menggunakan bahasa atau kata-kata, sedangkan simbol non verbal dikenal dengan bahasa isyarat atau kode. Pesan verbal dalam pemakaiannya menggunakan bahasa atau suara dalam proses komunikasi. Bahasa dan komunikasi merupakan dua bagian yang saling melengkapi. Pesan verbal atau bentuk komunikasi yang menggunakan bahasa adalah suatu kegiatan atau tindakan yang digunakan oleh semua manusia dalam kehidupan sehari-hari. Bahasa biasanya memiliki beberapa fungsi seperti untuk menjuluki orang, objek. Bahasa juga biasa digunakan untuk meluapkan atau mengutarakan sebuah perasaan serta untuk menjelaskan sebuah pemikiran yang ingin diberitahukan kepada orang lain. Bahasa verbal juga disebut sebagai bentuk representasi suatu arti atau maksud dari sebuah objek atau konsep. Cangara (2014) menjelaskan, setidak-tidaknya ada tiga fungsi bahasa verbal yang erat hubungannya dalam menciptakan komunikasi yang efektif yaitu untuk mempelajari tentang dunia sekeliling kita, untuk membina hubungan yang baik diantara sesama manusia dan untuk menciptakan ikatan-ikatan dalam kehidupan manusia.

Sementara simbol nonverbal adalah semua bentuk isyarat yang bukan kata-kata. Menurut Larry A.Samovar dan Richard E. Porter (dalam Mulyana 2014), komunikasi non verbal meliputi semua rangsangan (kecuali rangsangan verbal) dalam sebuah setting (aturan) komunikasi, yang diproduksi oleh setiap orang atau individu, yang mempunyai nilai pesan potensial bagi pengirim atau penerima. Dalam bahasa lain, komunikasi non verbar merupakan perilaku yang disengaja ataupun tidak disengaja sebagai bagian dari peristiwa komunikasi, termasuk yang terkandung dalam tradisi parang pisang. Komunikasi nonverbal juga dianggap memiliki peranan yang sangat besar dalam kehidupan sehari-hari. Menurut Ray L.Birdwhisell (dalam Mulyana, 2014) 65\% dari komunikasi tatap muka adalah nonverbal, sementara menurut Albert Mehrabian, 93\% dari semua makna sosial dalam komunikasi tatap muka diperoleh dari isyarat-isyarat non verbal Lebih jauh, Jurgen Ruesch (dalam Mulyana, 2014) juga mengklasifikasi nonverbal menjadi tiga bagian. Pertama, sign language (bahasa tanda) yaitu tanda yang dihasilkan dari tindakan yang disengaja dibuat untuk menunjukkan maksud tertentu seperti bahasa isyarat. Kedua action language (bahasa tindakan), yaitu semua gerakan tubuh yang tidak digunakan secara ekslusif untuk memberikan sinyal. Dan ketiga object language (bahasa objek) yaitu tanda dari benda atau objek seperti pakaian, bendera, gambar dan lain sebagainya.

Bersadarkan penjelasan di atas, simbolisasi atau penggunaan lambang pada tradisi parang pisang di atas merupakan hal yang pokok. Bahkan ritual- ritual yang dilakukan dalam tradisi parang pisang itu mengandung komunikasi ritual yang dilakukan seperti petatah petitih minang yang diucapkan sebagai bentuk komunikasi yang dilakukan oleh kedua belah pihak, penggunaan atribut yang mengandung makna, serta tindakan pemisahan kedua bayi. Dari seluruh ritual tersebut merupakan proses komunikasi yang menyiratkan pesan serta makna penting dari setiap prosesnya.

Setidaknya ada beberapa simbol verbal dan non verbal dalam tradisi parang pisang tersebut. Hasil observasi dan wawancana di lapangan menunjukkan beberapa simbol itu, sebagaimana berikut ini; (Pertama) simbol verbal, ditemui dalam tradisi ini penggunaan petatah petitih minang misalnya adalah simbol verbal berupa bahasa yang digunakan dalam proses komunikasi selama tradisi berlangsung. Petatah petitih minang tersebut cenderung terdengar seperti sajak atau pantun kuno dimana dalam pengucapannya terdapat makna seperti ajakan, permintaan maaf, 
bermakna menantang, serta ada makna hiburan di dalamnya. Petatah petitih minang itu (salah satu bentuk sastra lisan minangkabau yang berbentuk puisi dan berisi kalimat atau ungkapan yang mengadung pengertian yang dalam, luas, tepat, halus dan kiasan) juga merupakan komunikasi yang khas sebagai bentuk kearifan lokal.

Sementara (Kedua) simbol non verbal dalam tradisi parang pisang ini terdiri dari beberapa benda atau objek yang digunakan dimana juga memiliki makna di dalamnya. Adapun objek atau benda yang digunakan dalam tradisi itu sebagai berikut: (a). Si Muntu, dalam hal ini si muntu adalah orang yang memakai atribut dari daun pisang kering. Seluruh badannya ditutupi oleh daun pisang dan mukanya memakai topeng. Si muntu dimaknai sebagai boneka yang dibawa sebagai hadiah oleh keluarga induak bako. Dalam acara hiburan, si muntu bertugas sebagai penghibur untuk masyarakat dimana si muntu akan berlari-lari mengejar anak-anak atau warga yang menyaksikan acara tersebut.

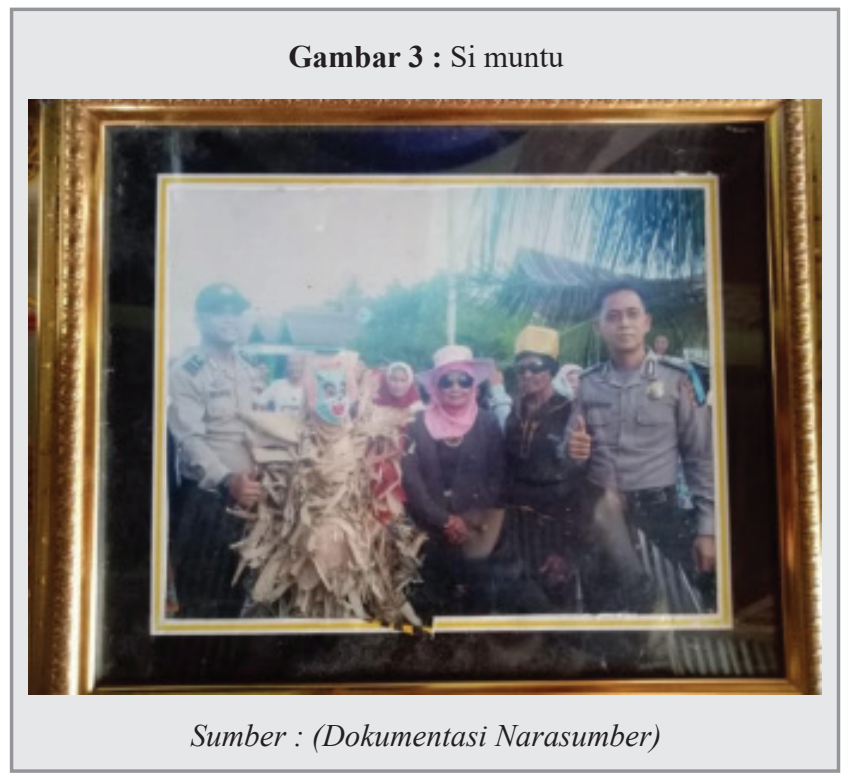

Selanjutnya adalah (b) Pisang Rebus, ini awalnya bermakna sebagai hantaran atau buah tangan. Dimana dalam adat minang ketika seseorang ingin datang ke rumah orang lain, perlu bahkan harus membawa buah tangan atau oleh-oleh sebagai bentuk sopan santun. Namun karna adanya penolakan, buah pisang yang sudah direbus tadi beralih menjadi peluru untuk perang. Pisang sebagai senajat itu umumnya di letakkan di dalam wadah besar yang disebut baskom. Menurut penuturan narasumber, alasan dipakainya buah pisang karena salah satu hasil bumi yang terkenal di Surantih adalah pisang batu medan. Sehingga buah pisang adalah buah yang mudah untuk didapati di daerah tersebut.

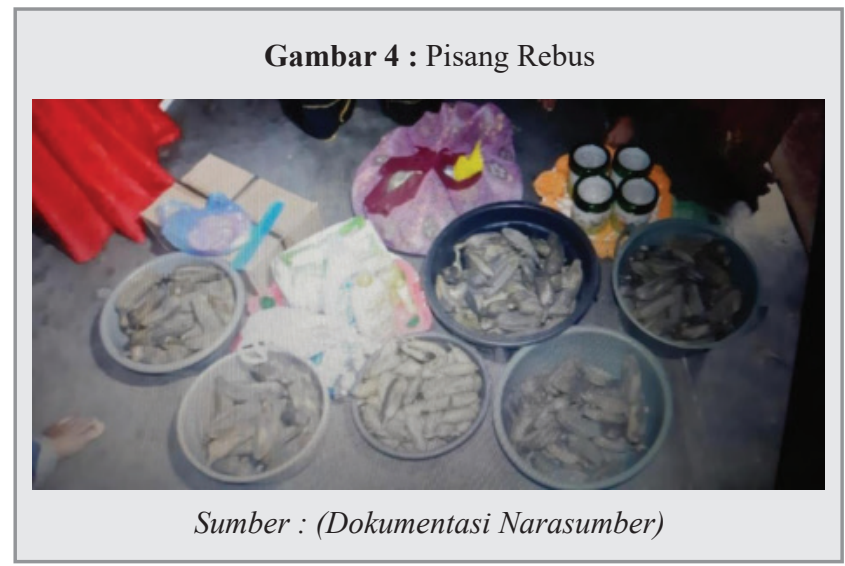

Selain pisang rebus, simbol non verbal lainnya adalah (c) Daun Sirih, daun sirih atau dalam bahasa minang disebut siriah langguai memiliki banyak makna. Daun sirih dan beberapa bahan menyirih lainnya di letakkan di dalam wadah yang disebut carano. Siriah langguai memiliki makna yang berbeda-beda sesuai dengan acara yang sedang dilaksanakan. Namun dalam garis besar siriah langguai melambangkan kesucian dan sakral. Dalam acara ini siriah langguai bermakna sebagai permintaan maaf dan ajakan berdamai. Seorang informan bernama Sri Yuliyesti menjelaskan seperti ini;

"Siriah langguai ko banyak makna dalam adat minang. Satiok acara, pasti beda lo artinyo. Kok dalam acara parang pisang ko, siriah langguai ko dimaknai sebagai permintaan maafjo ajakan berdamai",

"Siriah langguai ini mempunyai banyak 
makna. Setiap acara, pasti berbeda-beda artinya. Dalam acara parang pisang ini, siriah langguai dimaknai sebagai permintaan maaf dan ajakan berdamai”.

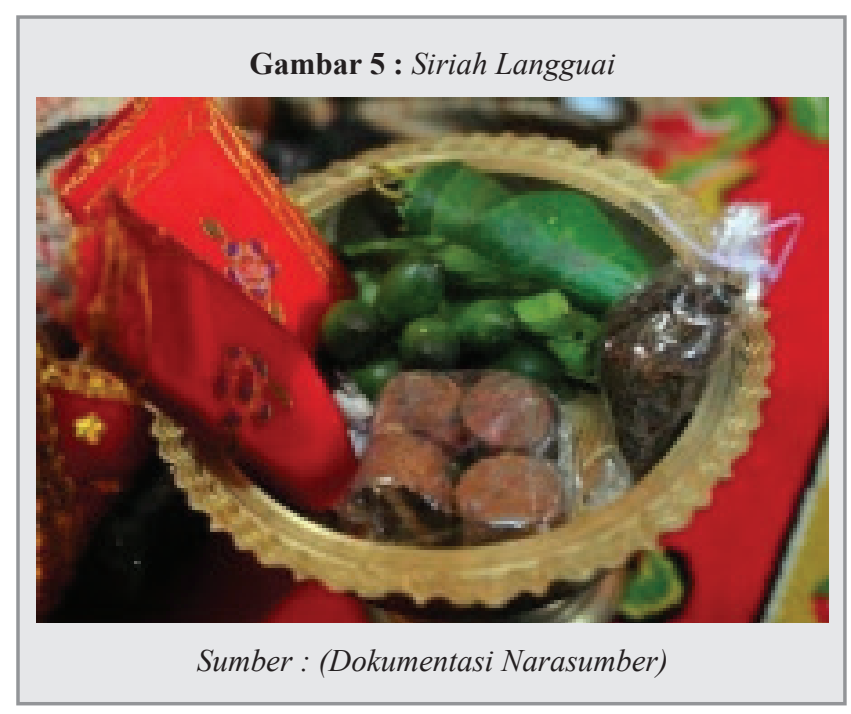

Terakhir adalah (d) Kudo Kepang, kudo kepang adalah sebatang pelepah pohon kelapa kering yang ditunggangi oleh manusia sehingga terlihat seperti kuda, memiliki makna sebagai mainan yang diberikan oleh induak bako kepada si bayi. Tujuan dari dibawakannya mainan kudo kepang dan boneka si muntu ini adalah agar si bayi mau di bawa oleh keluarga induak bako dan orang tua mereka mneyetujui. Dalam artian lain mainan dan boneka dibawa sebagai bentuk bujukan.

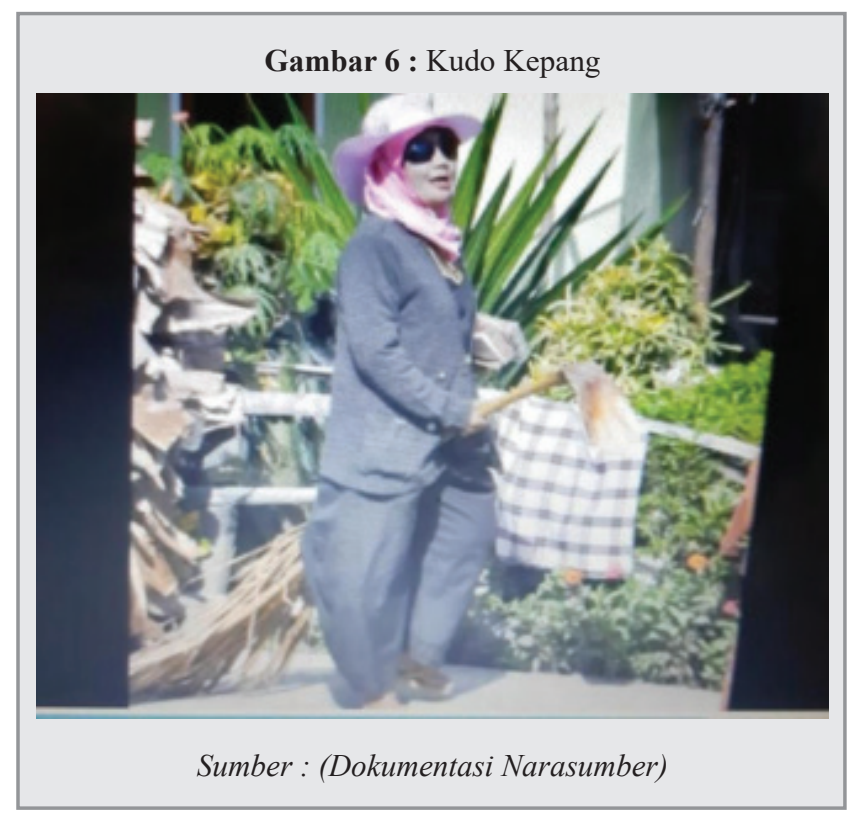

\section{KESIMPULAN}

Dari penjelasan di atas, artikel ini secara khusus telah menjelaskan tentang tradisi parang pisang sebagai komunikasi ritual. Sebagai tradisi, parang pisang jelas merupakan gambaran sikap dari perilaku manusia yang telah berproses dalam waktu lama dan dilaksanakan secara turun temurun, dan tradisi ini juga telah dipengaruhi oleh kecenderungan untuk berbuat sesuatu dan mengulang sesuatu sehingga menjadi kebiasaan. Secara umum, tradisi semacam ini, termasuk parang pisang merupakan entitas sekaligus identitas pada kelompok sosial tertentu yang secara substansial berusaha untuk dilestarikan (Zike, 2019).

Pada masyarakat Surantih, menyelenggarakan tradisi parang pisang ini adalah serangkaian komunikasi ritual yang memungkinkan mereka berbagi komitmen emosional dan menjadi perekat bagi kepaduan mereka. Atau dalam pemahaman kita, komunikasi ritual parang pisang itu dapat memberikan rasa nyaman akan keteramalan (a sense of predictability). Atau setidak-tidaknya dapat memberikan rasa aman terhadap apa yang menjadi pengetahuan mereka ketika ritual itu tidak dilakukan. Oleh karena itu, komunikasi ritual parang pisang ini dapat dikategorikan sebagai proses penafsiran pesan dari sebuah kelompok masyarakat atas aktifitas religi dan sistem kepercayaan yang mereka anut. Penafsiranpenafiran yang dimaksud adalah terhadap simbolsimbol tertentu yang menandakan terjadinya proses komunikasi ritual tersebut. Sebagaimana juga ditegaskan oleh Susanti (2015) bahwa ritual dapat menciptakan dan memelihara mitos, adat sosial dan agama. Ritual pertamanya bersifat sosial kemudian bersifat ekonomis lalu berkembang menjadi tata cara suci agama.

Akhirnya, dapat dijelaskan bahwa komunikasi ritual parang pisang pada masyarakat Surantih merupakan tradisi sebagai bagian dari kebudayaan 
lokal, yang prosesnya dimulai dengan arak-arakan keluarga induak bako menuju ke rumah bayi kembar sepasang. Tujuannya adalah untuk mengambil salah satu bayi. Pengambilan salah satu bayi ini dipercaya oleh masyarakat setempat untuk memutus rasa cinta agar mereka tidak kawin satu darah kelak. Namun arak-arakan induak bako itu ditolak oleh keluarga si bayi. Karena induak bako tidak terima dengan penolakan, maka terjadilah pelemparan pisang yang menyimbolkan kemarahan. Tradisi parang pisang ini dilakukan dan diikuti oleh semua keluarga besar kedua belah pihak, serta juga mengundang masyarakat sekitar untuk ikut merayakan. Setelah proses inti selesai, pihak keluarga si bayi akan mengundang masyarakat dan keluarga induak bako untuk makan bersama di rumah si bayi. Keluarga bayi atau orang tua bayi akan menjamu masyarakat dan para pemuka adat. Proses arak-arakan hingga pelemparan pisang merupakan bentuk komunikasi ritual, dimana dalam komunikasi ritual terdapat pesan yang direpresentasikan dalam simbol verbal dan non verbal.

Simbol verbal berupa petatah petitih minang yang terdengar seperti sajak. Atau berupa bahasa yang digunakan dalam proses komunikasi selama acara berlangsung. Simbol non verbal yang terdapat dalam acara ini berupa objek atau peralatan yang digunakan Adapun benda tersebut seperti si muntu, siriah langguai, kudo kepang. Makna yang terkandung dalam komunikasi ritual tradisi parang pisang ini adalah untuk memerangi batin kedua bayi kembar yang mereka percayai agar tidak adanya timbul rasa saling suka ketika mereka sudah dewasa nanti.

\section{DAFTAR PUSTAKA}

Afrizal. 2014. Metode Penelitian Kualitatif. Jakarta: Rajagrafindo.

Andung, Petrus Ana.2010. Komunikasi Ritual
Natoni Masyarakat Adat Boti Dalam di Nusa Tenggara Timur. Jurnal Ilmu Komunikasi, Volume 8, Nomor 1, Januari-April 2010. Hal 36-44.

Cangara, Hafied. 2014. Pengantar Ilmu Komunikasi. Jakarta: Rajawali Pers.

HonestDocs. 2019. Pentingnya Mengetahui Bahaya Perkawinan Sedarah bagi Kesehatan. https://kumparan.com/honestdocs/pentingnyamengetahui-bahaya-perkawinan-sedarahbagi-kesehatan-1rP0DSHYTDo.

Kayo, AI Mangindo. 2015. Tradisi Parang Pisang, Upaya Mencegah Kawin dengan Kembaran ala Kenagarian Ampalu https://www.valora. co.id/berita/1185/tradisi-parang-pisang-upayamencegah-kawin-dengan-kembaran-alakenagarian-ampalu.html

Maulana, Faisal. 2018. Makna Simbolik Pada Ritual Basapa Sebagai Tradisi di Kecamatan Ulakan Tapakis, Kabupaten Padang Pariaman: Padang

Mulyana, Deddy. 2014. Ilmu Komunikasi Suatu Pengantar. Bandung: PT. Remaja Rosdakarya Umar, Nugrah Juniar. 2018. Penggunaan Simbol-Simbol Komunikasi Non Verbal Antara Pengungsi Iran dan Warga Lokal di Makassar. Jurnal Komunikasi KAREBA. Juli-Desember. Vol 7 No.2

Sair, A. 2019; Etika Masyarakat Pandalungan Dalam Merajut Kebhinekaan (Agama), Jurnal Sosiologi Pendidikan Humanis Vol. 4, No. 1, Juli 2019

Sugiyono. (2013). Metode Penelitian Pendidikan. Bandung: Alfabeta.

Susanti, Elvi. 2015. Komunikasi Ritual Tradisi Tujuh

Bulanan : Studi Etnografi Komunikasi bagi Etnis Jawa di Desa Pengarungan Kecamatan Tergamba Kabupaten Labuhanbatu Selatan. Jom FISIP Volume 2 No.2 Oktober 2015.

Zike Martha, 2019 (Informasi dari seminar kebudayaan dan hubungan masyarakat) 


\section{Website}

https://id.m.wikipedia.org/wiki/Budaya_Indonesia,

Diakses pada 15 November 2020

https://www.google.com/amp/s/pakarkomunikasi.

com/simbol-simbol-dalam-komunikasi-antar-

budaya/amp. Diakses pada 23 November 2020

https://langgam.id/nagari-surantih-sutera-

kabupaten-pesisir-selatan/. Diakses pada

tanggal 22 Maret 2020

https://id.wikipedia.org/wiki/Nagari, Diakses pada tanggal 20 Desember 2020

https://www.worldometers.info/world-population/, diakses pada tanggal 13 Agustus 2020 